\title{
TOWARD ESTABLISHING A SUSTAINABLE TOURISM ON THE TALIMBARU VILLAGE IN THE KARO REGENCY
}

\author{
Rini Herliani, Andri Zainal* \\ Accounting Education Department, Faculty of Economics, Universitas Negeri Medan, Medan, Indonesia \\ * Corresponding Author: andrizainal@unimed.ac.id
}

\begin{abstract}
This article aims to present a descriptive analysis related to the Embung Talimbaru Ecotourism Area (ETEA). The development of this ETEA refers to the actualization of the Talimbaru Village Mid-Term Development Plan (RPJMD) for 2016-2021 which has the potential for the realization of an ecotourism area that is not only suitable to support the Lake Toba Geopark Area, but also as the next New Bali program. Previous studies have highlighted the importance of strengthening the capacity of local communities in the development of community-based tourism that was characteristic of the previous era of tourism in Karo District. The priority issues that underline the importance of implementing business management and good governance in Village Owned Enterprise (known as BUMDES) activities, especially with the acceleration of the management of the ETEA as a leading local nature tourism object. In addition, the success of the sustainable management of the ETEA will be largely determined by the competence and professionalism of the human resources and infrastructure of the associated tourism village management ecosystem. Strategic actualization of the embodiment of a descriptive approach to the development of ETEA is presented in detail in the discussion segment toward preparing for Community Service program in both mono and multi-year schemes.
\end{abstract}

Keywords: Community-Based Tourism; Descriptive Approach; Embung Talimbaru Ecotourism Area; Community Service Program; Karo.

\section{INTRODUCTION}

Talimbaru Village, located in the Barusjahe Subdistrict, about $15 \mathrm{Km}$ from the capital of Karo Regency, or 20 minutes away by car, is the last village or directly borders with Simalungun Regency. Talimbaru Village has been declared a new tourism village in Karo District and this declaration has been established in the 2016-2020 Medium-Term Village Development Plan (RPJMD). Talimbaru Village is led by Mr. Ferianto Tarigan where in his leadership era he has established work programs such as:

- construction of a hobbit house, "sapo angina" (hut with the use of traditional Karo characters and ornaments),

- opening of a jungle track that connects directly to the resident / village settlement;

which is intended as a superior ecotourism vehicle that is expected to make the Ecopark Talimbaru Tourism Village that still maintains local culture and wisdom and improves the economy of the surrounding community. Geographically, access to the Talimbaru Village is not so far from / to the karo district capital, Kabanjahe City, also to other tourist attractions, such as Tongging and Sipiso-piso Waterfall.

One of the leading tourist spots in the village of Talimbaru is Embung whose existence is quite well known to a limited extent by local residents who live around the District of Karo. During this time, according to the Head of Talimbaru Village, Mr. Ferianto Tarigan, the existence of the reservoir is only functioned as a fishing pond that has no impact on the local Original Revenue (PAD). Initiatives related to the development of ponds as fishing ponds have also been realized by the local village government through a 20,000 goldfish and tilapia sowing program in the period of September 2018. This program is realized using village funds to be further managed by the local village-owned enterprises (BUMDES).

However, the existence and sustainability of this program raises its own issues where the presence of tilapia and goldfish is relatively potential for pollution and a decrease in water quality due to fish dung and the deposition of protein and phosphate from fish feed. The presence of excessive phosphate has an impact on eutrophication and anoxic water as reported in Lake Cirata, Purwakarta, West Java (see: https://www.hetanews.com/article/87619/descentkualitas-air-danau-toba-akibat- kja). Feed (usually in the form of pellets) that is not consumed by fish results in sewage deposition in water bodies that changes the composition of proteins into nitrogen and phosphorus. As a result, the quality of water content will decrease significantly and cause unpleasant odors due to turbidity of water. Although this condition is relatively still not happening in Talimbaru dam, mitigation and preventive actions are important to be implemented so that it does not bring negative impacts on the ecosystem around the dam.

BUMDES readiness as a professional attraction manager in terms of human resources (HR) also has not materialized significantly. This condition is reflected in the absence of tourism awareness groups and environmentally conscious 
groups (DARWIS and DARLING) formed by the local village government both with youth group groups and youths who live in two hamlets within Talimbaru Village. The absence of a program to strengthen the capacity of human resources driving the Talimbaru reservoir tourism is an inevitable factor for the optimal development of reservoir tourism in Talimbaru Village. Although the Talimbaru tourism village development program has become one of the programs contained in the 2016-2021 Medium-Term Village Development Plan (RPJMD), due to the limited understanding and expertise of village officials in developing work programs, it has an impact on inefficiency and ineffectiveness in management village funds for sustainable regional development through strengthening intellectual capital, especially in Talimbaru Village.

In connection with the preparation of work programs, one of the outputs of the rural information system that has an important role as a rural information guard is the village profile. The compilation of village profiles should have a legal basis as stipulated in Law Number 6 of 2014 concerning Villages, Pemendagri No. 12 of 2007 concerning Guidelines for the Compilation and Utilization of Village and Kelurahan Profile Data, and Minister of Home Affairs Letter 414.3 / 316 / PMD dated 7 February concerning Village / Kelurahan Profile Data Collection System. The government establishes guidelines for the preparation and utilization of village and kelurahan profile data as a legal umbrella for regions and villages / kelurahans in establishing programs and activities for collecting, processing, analyzing, publicizing and utilizing village and kelurahan profile data (see: Urgency of Village Profiling and Utilizing Data Profiles - published at http://www.lsn.or.id/index.php/2019/01/23/urgensi-pusunan-dan-payaya-data-profildesa). Village profiles can also be used as a means to gather accurate and up-to-date data and information about villages and sub-districts, as well as a medium of communication between the central and regional governments. Until now, Talimbaru Village does not yet have a representative village profile in meeting the needs as previously explained; both in print format (bulletin boards or electronically on the internet-based village portal portal). The limited coverage of the internet network, especially from national cellular service providers (Telkomsel, Indosat and XL-Axiata) also becomes an obstacle apart from the main one which is the competency of the Talimbaru village administrative device human resources. So that the absence of Talimbaru village profiles in both formats limits internal and external parties' access to information while monitoring the potential and level of development and as a source of data for the community, potential investors and ministries and institutions wishing to plan short, medium and long term programs. based on Talimbaru village data.

This article is intended to elaborate alternative solutions that can be followed up by relevant stakeholders, especially the local village government, in realizing a strategic plan to develop Talimbaru village as a tourism village with an embung as an ecotourism tourism icon. The alternative elaboration of the intended solution resulted from a qualitative study that was developed based on field observations, the results of interviews with elements in Talimbaru village governance meetings and relevant documentation studies. Among them, the RPJMD of Talimbaru village document for the period of 2016-2021, minor and major library sources that are relevant to the development of ecotourism based on local wisdom.

\section{MATERIALS AND METHODS OF IMPLEMENTATION}

As explained in the previous introduction section, the relevant strategic action plan for the realization of the Embung Talimbaru Ecotourism Area (ETEA) in the early stages should be focused on solving problems related to the management of Talimbaru BUMDES. Specifically, the specific problem in question consists of:

a) The absence of Branding Management and Talimbaru's BUMDES governance, especially related to the professional management of tourism villages.

b) Physical and electronic documents relevant to the village profile and the management of the Talimbaru Embung as a leading tourist attraction that has not been properly presented.

c) The quality of HR both members, management, managers and supervisors is still not competent with the DARWIS and DARLING groups not functioning.

d) Has never been carried out education and outreach related to the existence and conservation of the Talimbaru Village reservoir which will be further managed as an Ecopark and the absence of basic environmental hygiene infrastructure

Based on the description of the specific problems above, it can be seen that the priority issues underline the importance of implementing business management and good governance in BUMDES activities, especially with the acceleration of the management of the Talimbaru Embung as a pre-eminent natural attraction. In addition, the success of the sustainable management of the Talimbaru tourism village will be largely determined by the competence and professionalism of the human resources and infrastructure of the associated tourism village management ecosystem.

ETEA through community service programs is counseling, training and assistance in strengthening BUMDES governance as well as updating the content and design of village profiles and village tourism portals. In this case the program head and members act as facilitators.

1) Implementation Method of PKM

The community service program is carried out in stages, namely: 
a) Informing about the implementation of activities to the village head and manager of Talimbaru BUMDES.

b) Provide counseling and training on the benefits and ways to manage rural tourism via BUMDES.

c) Provide workshops and mentoring on tourism management and development of the village digital portal and the Talimbaru ecotourism area (Talimbaru Ecopark).

2) Evaluation of Success

The results received from this activity were analyzed again by the executor of this PKM activity to determine the level of success of the activity and the shortcomings and things that must be done again so that the objectives of the activity can be implemented well and provide practical benefits to all parties involved in strengthening managerial capacity Governance of Talimbaru BUMDES in Barusjahe Subdistrict as an effort in the Development of the Embung into the Ecopark of the Karo District.

Graphic illustrations related to the implementation of methods and approaches for resolving priority issues agreed with partners are presented in Figure 1 below.
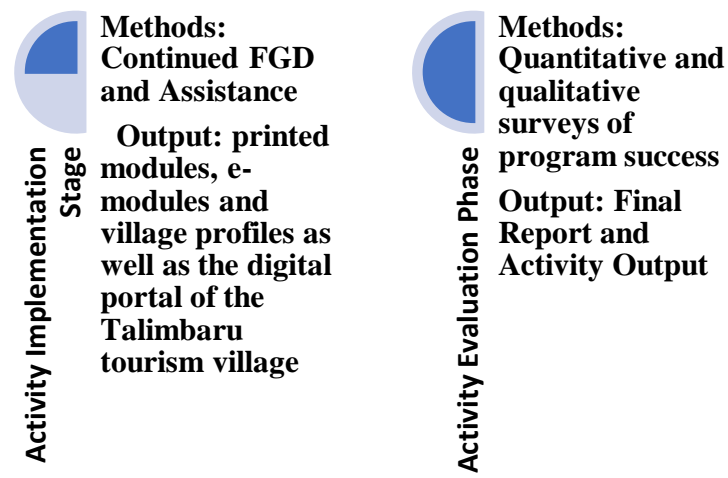

Figure 1. Method of Approach to Each Stage of Activity Implementation

\section{DISCUSSION}

The method of implementing activities for solving problems related to ETEA development through community service programs (PKM) is counseling, training and mentoring to strengthen BUMDES governance and updating the content and design of village profiles and village tourism portals.

1) Implementation Method of PKM

The community service program is carried out in stages, namely:

a) Informing about the implementation of activities to the village head and manager of Talimbaru BUMDES.

b) Provide counseling and training on the benefits and ways to manage rural tourism via BUMDES.

c) Provide workshops and mentoring on tourism management and development of the village digital portal and the Talimbaru ecotourism area (Talimbaru Ecopark).

\section{2) Evaluation of Success}

The results received from this activity were analyzed again by the executor of this PKM activity to determine the level of success of the activity and the shortcomings and things that must be done again so that the objectives of the activity can be implemented well and provide practical benefits to all parties involved in strengthening managerial capacity Governance of Talimbaru BUMDES in Barusjahe Subdistrict as an effort in the Development of the Embung into the Ecopark of the Karo District.

In detail, the actual ETEA development program will lead to the realization of several measurable, output-based follow-ups. Some of the follow-up that is meant can be reviewed from Table 1 below.

Table 1. Matrix of Priority Problems and Solutions

\begin{tabular}{|c|c|c|c|}
\hline No & $\begin{array}{l}\text { Priority } \\
\text { Problems }\end{array}$ & Alternative Solutions & Output Target \\
\hline 1 & $\begin{array}{lr}\text { Improved } & \\
\text { business } \\
\text { governance and } \\
\text { management and } \\
\text { branding from } \\
\text { BUMDES } \\
\text { Talimbaru. }\end{array}$ & $\begin{array}{l}\text { - Workshop on basic tourism } \\
\text { management for increasing individual } \\
\text { and institutional competence in the } \\
\text { DARWIS and DARLING groups } \\
\text { managing the Talimbaru tourism } \\
\text { village. } \\
\text { - Actualization of environmentally } \\
\text { conscious campaigns around the } \\
\text { Talimbaru ecotourism area }\end{array}$ & $\begin{array}{l}\text { - } 1 \text { (one) set of print modules } \\
\text { and e-module for Talimbaru } \\
\text { tourism village management } \\
\text { - Construction of } 1 \text { (one) set of } \\
\text { recycle bins }\end{array}$ \\
\hline
\end{tabular}




\begin{tabular}{|c|c|c|c|}
\hline 2 & $\begin{array}{l}\text { Publication of } \\
\text { Talimbaru } \\
\text { reservoir profiles } \\
\text { and activities as a } \\
\text { leading tourist } \\
\text { attraction online } \\
\text { using the website }\end{array}$ & $\begin{array}{l}\text { - Assistance in the making and updating } \\
\text { of village profiles based on print and } \\
\text { online } \\
\text { - Assistance with the creation and } \\
\text { operation of the Talimbaru Ecopark } \\
\text { website }\end{array}$ & $\begin{array}{l}\text { - } 1 \text { (one) printed document and } \\
\text { electronic portal containing } \\
\text { the profile of the village of } \\
\text { Talimbaru } \\
\text { - Development of } 1 \text { (one) } \\
\text { website page and / or other } \\
\text { social media (Facebook and } \\
\text { Instagram) }\end{array}$ \\
\hline
\end{tabular}

Actualization of this method is relatively appropriate to be translated into the ETEA development program based on strengthening the capacity of local resources through a community-based empowerment approach in this case the DARWIS and DARLING communities that will be under the auspices of the Talimbaru BUMDES. This communitybased empowerment approach is particularly important to be implemented in the Toba ecotourism area which has been established by the Working Cabinet government for the 2014-2019 period with the heading 10 New Bali Projects in Indonesia (10 New Bali Projects in Indonesia) where Karo District is the support. Strengthening local capacity becomes strategic in this approach for accelerating the achievement of the process of creating a network of interactions based on effective collaboration from all communities that can support sustainable development. As underlined by Zaenal et al. (2016), this approach to developing local community-based tourism in a sustainable manner can improve the quality of life of civil society as a determinant of the continuity of local wisdom reflected in the values that apply to the local community.

\section{CONCLUSION}

This article describes a descriptive applied study (related approach) related to ETEA development based on a community-based tourism development approach. In line with the study of Zaenal et al. (2016), ETEA development efforts cannot be released with local capacity building efforts that make them the main actors in the realization of ecotourism areas that are not only suitable to support the Lake Toba Geopark Area, but also as the next New Bali program. The tourist area in Karo Regency has experienced its heyday in the 1980s to 1990s. The role of the local community is very strong in the golden era of tourism in the Karo District and this should be the foundation for the development of the blueprint and the development model of the Ecotourism Area in the Karo District based on the strengthening of local human resources with global standards.

\section{ACKNOWLEDGMENT}

The team of authors would like to thank the Research and Community Service Institute of Medan State University for giving us the opportunity to develop a strategic plan related to the development of the Talimbaru Embung Ecotourism Area and actualize it in 2019. Furthermore, we also thank all elements of the Talimbaru MUSPIDES especially the Talimbaru Village Government in Barusjahe sub-district, Karo District, which has given us access to explore the potential of ecotourism and related local communities for modeling the proposed ETEA development in the context of this descriptive approach.

\section{REFERENCES}

Anonim. https://www.hetanews.com/article/87619/penurunan-kualitas-air-danau-toba-akibat-kja.

Anonim. Urgensi Penyusunan dan Pendayagunaan Data Profil Desa - dipublikasikan di http://www.lsn.or.id/index.php/2019/01/23/urgensi-penyusunan-dan-pendayagunaan-data-profil-desa

Zaenal, A., Sagala, G. H., Armayanti, N. (2016). Analisis Partisipasi Masyarakat Dalam Peningkatan Daya Saing Pariwisata di Kawasan Geopark Danau Toba. Jurnal Akuntansi Dan Bisnis. Vol. 16, No. 1, p. 1-9. 